\title{
The Opinions of Nurses Who Study for a Master's Degree With Regards to Distance Education
}

\author{
Gönül Sarıkaya ${ }^{1}$
}

\section{ARTICLE INFO}

\section{Article History:}

Received 08.04.2017

Received in revised form

09.05.2017

Accepted

Available online 01.07.2017

\begin{abstract}
This study's purpose is to determine the opinions of nurses who study for a master's degree via distance education with respect to distance education.The research sample consists of 20 nurses who are employed at the Hatay district of the city of Izmir.In the research, 6 questions were asked to nurses in order to determine their views and opinions about distance education practices, the problems they experienced and the positive and negative aspects of the distance education method. The interviews which were audio-recorded were then transcripted into written documents and their data were analyzed through the descriptive analysis method.The research results revealed that master's degree education through distance learning was generally considered to be effective. Master's degree education through distance learning met the students' expectations of the master's degree education. The immediate reasons why nurses preferred distance learning turned out to be the work hours during daytime due to employment and the duties and responsibilities that are undertaken due to marital status. It was found that the most positive aspect of a master's degree education through distance learning was time and location flexibility. It provides a great deal of ease and advantage in the education of occupational groups who work full time such as nurses. The difficulties they experienced during the distance master's degree education turned out to be information technology problems and lack of sufficient interaction. According to the results of the study, it's possible to put forward suggestions that would increase the availability of master's degree education through distance learning for more people so that women who are actively employed and who also have serious duties and responsibilities in family life can engage in lifelong learning and realize their potentials.
\end{abstract}

C 2017 IJERE. All rights reserved

Keywords:

Learning nurses, master's degree, distance education.

\section{INTRODUCTION}

In distance learning, individuals take on the responsibility of learning by themselves and there's no need for the learner and the teacher to be at the same location physically. Distance learning has a history of two centuries and it's frequently used in meeting the education needs of our time. It eliminates the distance in terms of location and the transportation problems, and provides equal opportunities via technology, as well as efficient use of time without impacting the individuals' flow of life, while supporting the learners to receive an education on their own. It also provides convenience to disabled individuals or individuals who couldn't complete or even begin their education. All these factors raise the interest in distance learning and accelerate its improvement (Kaya and Onder, 2002).

The main reasons why distance education is required in addition to traditional education can be listed as; rapid industrialization, population growth, economic problems and the increase in demand for education and training. Distance education which is aimed at providing equal opportunities in education and training and meeting the demand for education and training, is "A method of teaching which is implemented at a specific center through a specially designed curriculum and various platforms in order to provide the interaction and communication between those who organize and implement the educational activities and learners in cases where there are no means to continue with the classroom activities because of the limitations of the traditional educational methods" (Alkan, 1987).

It is considered that distance education could be the type of education program that would meet the needs of the society and the individual through the changes and improvements in information technologies. Distance education is an educational revolution which enriches the traditional formal education by making it personalized, easily accessible and economic (İsman and Dabaj, 2005: 59).

\footnotetext{
${ }^{1}$ Corresponding e-mail: elmayra_1980@hotmail.com
} 
The need for receiving an education is on the rise due to the developments in the concept of lifelong learning not only from an occupational point of view but also from a personal growth point of view. The increase in the number of learners along with the continuous demand for education in order to survive in the professional world have become the most important factors that introduced distance education as an alternative education system (Akca, 2006).

When distance education is assessed in terms of female students, it can be seen that a period of change has begun for women who on one hand continue their duties at home assuming the roles of mother and wife, while working on salary and keeping up with the demands of the city life on the other hand. As a result of that, it is questioned whether distance education is an option or an obligation for women (Sugur and Savran, 2006:214). One way of involving more women in education is to overcome barriers such as distance, time and multiple decisions by distance education. The real issue in a male-dominant society which ignores women's needs is not just the equality of educational rights for women but also their equality in the system (Hipp, 1997: 41).

According to a study of Susan May which she conducted in years 1990-1991 on nine women who were home-schooled, the flexibility of distance education is of great importance for women. Women are able to spare time for their children and their house chores first and then for their studies, thanks to distance education. Women don't have the same conditions as men. There are multiple tasks at hand for women. Women have to include distance education classes, the care of their children and their house chores all at the same time in their study plans. Despite all these negative aspects, women are still grateful for distance education (May, 1994: 242).

The concept of the "second shift" which is used by the sociologist Hochscild to emphasize the house chores that working women do after they come back home, brought about the concept of the "third shift" as an addition to their responsibilities at work and home, during which women improve their education through distance education applications. Kramarae attributed distance education being a "third shift" for many women, to the absence of change in the traditional roles of women including handling of the house chores and child care, in addition to their responsibilities in the professional life (Sugur and Savran, 2006: 208).

The fact that health care services rapidly changed, developed and became more complex in recent years, requires the nurses to gain information about these changes, to update their professional knowledge and application skills, to take more advantage of information technologies and most importantly to adopt the importance of lifelong learning (Willmer, 2005). One of the best ways to improve the education of nurses is to increase the availability of lifelong education programs which will enable them to continue with their education after their graduation. That being said, nurses who have responsibilities in their family lives in addition to their professional lives can encounter problems in accessing formal education programs because of their challenging and variable working hours (Boz, 2008), (Senyuva, 2013).

The education of nurses must be special and continuous so that they can be ready not only for existing health care conditions or problems but also for possible health care conditions or problems. Continuous education is undoubtedly important for the adaptation of nurses to the constant changes and improvements in health practices, through their knowledge and practice skills. However, as Beldarrin (2006) and Atack (2003) point out, nurses who are going through the adult stage of their lives are not able to receive formal education services and may encounter personal, professional and familial problems with regards to that (Boz and Kurubacak, 2008).

Distance education practices offer new opportunities to nurses who can't continue with their formal education programs due to reasons such as shift work conditions, familial reasons, time limitations and geographical distances, by eliminating these obstacles (Beldarrin, 2006), (Atack, 2003).

The National Council of State Boards of Nursing of the United States of America who states that the country's health would be at risk without a sufficient number of highly educated workforce of nurses, informs that raising the education level of nurses is of great importance in meeting the country's nursing requirements and offering a more effective and safer care of patients. Regardless of their entry levels to the profession, nurses are encouraged to pursue undergraduate, master's or doctorate degrees by the nursing 
council. Hence, distance education stands out as a new solution for nurses to continue with their education (Tri-Council,2010), (Yuksekdag, 2014).

The research problem statement:

What are the opinions of nurses who study for a master's degree with respect to distance education?

1-The goals of nurses for studying for a master's degree

2-Nurses' reasons for preferring distance education before they begin their studies for a master's degree

3-The contribution of a master's degree to nurses' profession

4-The problems they experience while they're studying for a master's degree through distance education

5-Whether they would prefer to study for a master's degree through distance education again or not

6-Whether their expectations of the master's degree through distance education were met or not

The purpose of the research is to take the opinions of the nurses who study for a master's degree through distance education, with respect to distance education.

At this point, the main goal is to reveal the positive and negative aspects and the superior and limiting attributes of distance education programs from the nurses' point of view.

This is considered to be important since it would reveal the needs of the female learners who are actively employed and who also have serious duties and responsibilities at home and since it would provide guidance for the preparation of distance education programs.

\section{METHOD}

The semi-structured interview technique which is one of the methods of qualitative research that is described as "the type of research where qualitative data collection methods such as observation, interview and document analysis are used and a qualitative process where events are described in their natural environment in a realistic and holistic manner" (Yildirim and Simsek, 2008) is used in the research.

The interview form which is developed to determine the opinions of the nurses who study for a master's degree through distance education, with regards to distance education, has been put into its final form in accordance with the views of the experts. The interview form includes six open-ended questions.

The opinions of nurses about the master's degree through distance education, the problems they experienced and solution suggestions were identified.

The sample in the study is identified with the convenience sampling method. In the convenience sampling method, "the researcher selects a case that is close by and easily accessible and s/he brings speed and practicality to the research" (Yildirim and Simsek, 2008). The sample of the research which is created with the convenience sampling method, consists of 20 nurses who are employed at a 2nd grade health organization in Izmir. All 20 of the nurses who make up the sample are female nurses. The average age of the nurses is 37.8 and the total average years of employment is 16.5.

The ages of the participants range from 29 to 49 . The participants' total years of employment range from 7 to 30 .

The interview form is used as a data collection method in the research. During the preparation stage of the interview questions, the literature was reviewed and 6 open-ended questions which would reflect the relevant sub problems in the best way were included in the interview form. Open-ended research questions "provide the researcher with the opportunity of handling the topic s/he wants to examine in a flexible and open-ended manner" (Yildirim and Simsek, 2008).

The interviews were held at dates and times that were scheduled according to the working hours of the nurses. The interviews were audio-recorded to prevent data loss and then transcripted. Written consent of the nurses were taken with respect to audio recordings. During the interviews, the nurses answered all the 12 questions that they were asked and they indicated their opinions.

The data acquired from the interviews were analyzed with the descriptive analysis method. Descriptive analysis consists of four stages; creating a framework for the descriptive analysis, processing of the data according to the thematic framework, identification of the findings and interpretation of the findings (Yildirim and Simsek, 2008). The thematic framework was identified for the analysis of the data by 
researchers. In this regard, the data were first coded separately by each researcher. Then the data that were compiled were compared and common codes were assigned to common themes unanimously.

The written texts which were generated from the interviews were examined repeatedly in order to code the data which fit the purpose of the research and the themes which explain the coded data in general were identified.

The acquired findings were organized in tables. The interviewed nurses are expressed in codes as N1N20. Direct quotes of the nurses' opinions were included in the interpretation of the findings.

\section{FINDINGS}

The purposes of nurses for studying for a master's degree is presented in Table 1.

Table 1. The opinions of the nurses with regards to their purposes for studying for a master's degree

\begin{tabular}{|c|c|c|c|}
\hline $\begin{array}{l}\text { Theme } \\
\text { (Categories) }\end{array}$ & Codes & $\mathbf{N}$ & $\%$ \\
\hline
\end{tabular}

\begin{tabular}{|c|c|c|c|}
\hline \multirow{4}{*}{$\begin{array}{l}\text { The purpose } \\
\text { of studying } \\
\text { for a master's } \\
\text { degree }\end{array}$} & Status (N4,N5,N6,N8,N9,N10,N11, N13,N14,N16,N17,N18) & 12 & 60 \\
\hline & (N3,N7,N8,N9,N11,N14,N15) & 7 & 35 \\
\hline & Professional development (N3,N10,N12,N16,N19,N20) & 6 & 30 \\
\hline & Personal development (N6,N8,N15,N16) & 4 & 20 \\
\hline & Interest (N1,N2,N14,N18) & 4 & 20 \\
\hline
\end{tabular}

When Table 1 is examined, it can be seen that gaining status is the most common purpose for studying for a master's degree $(60 \%)$. Other opinions of purposes can be listed as lifelong learning with a rate of $35 \%$, professional development with a rate of $30 \%$, personal development with a rate of $20 \%$ and interest with a rate of $20 \%$. The exact quotes of the nurses' opinions are presented below.

"First of all, there may be a change of status. I think it would be a contribution in retirement. I think that I'd be able to work especially at the newly opened medical vocational high schools as an educator or an expert educator." (N4)

"Lifelong learning is right up my alley. Learning new things can contribute to my profession or even to my kids." (N3)

Nurses' opinions with respect to their reasons for preferring distance education before they began their studies for a master's degree is presented in Table 2.

Table 2. Nurses' opinions with respect to their reasons for preferring distance education before they began their studies for a master's degree

\begin{tabular}{llll}
\hline $\begin{array}{l}\text { Theme } \\
\text { (Categories) }\end{array}$ & Codes & N & $\%$ \\
\hline $\begin{array}{l}\text { Reason for } \\
\text { preferring }\end{array}$ & Family life (N1,N2,N8,N9,N10,N13,N14,N16,N17,N19) & 10 & 50 \\
distance & Professional life (N2,N3,N7,N8,N9,N10,N11,N12,N13) & 9 & 45 \\
education & Time-location flexibility (N3,N4,N5,N6,N13,N14,N18,N20) & 8 & 40 \\
& Scarcity of time (N1,N10,N15,N16) & 4 & 20
\end{tabular}

When Table 2 is examined, it can be seen that family life is the most common reason for preferring distance education before beginning to study for a master's degree (50\%). Other reasons can be listed as professional 
life with a rate of $45 \%$, time-location flexibility with a rate of $40 \%$ and scarcity of time with a rate of $20 \%$. The exact quotes of the nurses' opinions are presented below.

"Well, I'm 34. I'm married. I have a child. For that reason, I don't have much time. I felt that distance education was easier for me since I didn't have the time to receive a formal education. I preferred this because it's easier to connect and communicate from home." (N1)

"We would have huge problems with working hours in formal education. That's our biggest problem. And naturally we'd have things to do at home after leaving school. It's unfortunately problematic to do them both for a working woman, married with kids. Distance education has the qualities to account for all these difficulties. At home, we're in a position where we can comfortably attend classes whenever we want to. That's why I preferred distance education." (N2)

Table 3. The opinions of nurses with regards to the contribution of the master's degree to their profession

\begin{tabular}{|c|c|c|c|}
\hline $\begin{array}{l}\text { Theme } \\
\text { (Categories) }\end{array}$ & Codes & $\mathbf{N}$ & $\%$ \\
\hline \multirow{7}{*}{$\begin{array}{l}\text { The } \\
\text { contribution } \\
\text { of the master's } \\
\text { degree to your } \\
\text { profession }\end{array}$} & Increase in work efficiency $(\mathrm{N} 8, \mathrm{~N} 10, \mathrm{~N} 11, \mathrm{~N} 12, \mathrm{~N} 13, \mathrm{~N} 17)$ & 6 & 30 \\
\hline & Bilateral relations $(\mathrm{N} 1, \mathrm{~N} 2, \mathrm{~N} 3, \mathrm{~N} 14)$ & 4 & 20 \\
\hline & Status (N4,N6,N9,N19) & 4 & 20 \\
\hline & Professional development (N15,N16,N19,N20) & 4 & 20 \\
\hline & Planned work (N8,N11) & 2 & 10 \\
\hline & It has no contribution $(\mathrm{N} 5, \mathrm{~N} 18)$ & 2 & 10 \\
\hline & Empathy (N7) & 1 & 5 \\
\hline
\end{tabular}

When Table 3 is examined, it can be seen that increase in work efficiency is the most common contribution of the master's degree to the profession of nursing (30\%). Other opinions with regards to contributions can be listed as bilateral relations with a rate of $20 \%$, status with a rate of $20 \%$, professional development with a rate of $20 \%$, planned work with a rate of $10 \%$, no contributions with a rate of $10 \%$ and empathy with a rate of $5 \%$. The exact quotes of the nurses' opinions are presented below.

"I've performed the practical applications of what I've learned in addition to theoretical information. My efficiency in my profession has increased in this way."(N10)

"It had a great contribution to communication. It contributed the most to doctor-nurse relationships, nursesupervisor relationships and in our relationships with patients. The profession became more enjoyable. Now I can see why I was having difficulties. When I interact with people I can see the source of the problem, so I can solve my problems more easily." (N2)

The opinions of nurses with regards to the problems they experience while studying for a master's degree through distance education is presented in Table 4.

Table 4. The opinions of nurses with regards to the problems they experience while studying for a master's degree through distance education

\begin{tabular}{lll}
\hline $\begin{array}{l}\text { Theme } \\
\text { (Categories) }\end{array}$ & Codes & N \\
\hline
\end{tabular}

Problems IT problems (N1,N2,N3,N5,N6,N7, 


\begin{tabular}{llll}
\hline $\begin{array}{l}\text { experienced } \\
\text { during }\end{array}$ & $\mathrm{N} 8, \mathrm{~N} 10, \mathrm{N11,N13,N14,N19)}$ & 12 & 60 \\
$\begin{array}{l}\text { studying for a } \\
\text { master's }\end{array}$ & Lack of sufficient interaction (N3,N10,N11,N13,N14,N15,N19) & 7 & 35 \\
$\begin{array}{l}\text { degree } \\
\text { through }\end{array}$ & Class hours being early (N7,N8,N12) & 4 & 20 \\
$\begin{array}{l}\text { distance } \\
\text { education }\end{array}$ & Adaptation to technology (N4,N5,N9) & 3 & 15 \\
& & 3 & 15 \\
\end{tabular}

When Table 4 is examined, it can be seen that IT problems is the most commonly experienced problem while studying for a master's degree through distance education (60\%). Other experienced problems can be listed as lack of sufficient interaction with a rate of $35 \%$, not being able to spare time for the family with a rate of $20 \%$, class hours being early with a rate of $15 \%$, adaptation to technology with a rate of $15 \%$, educational expenses with a rate of $10 \%$, homework with a rate of $10 \%$, distance of the university with a rate of $10 \%$, lack of written text books with a rate of $5 \%$ and accommodation with a rate of $5 \%$. The exact quotes of the nurses' opinions are presented below.

"For example, I believe that I learn better through face to face communication. Do you think that interaction is better? Yes. That's why I think distance education has such a disadvantage. The internet connection is cut off frequently, sometimes the volume goes down and I miss the class while asking a question. It has negative effects in that sense." (N3)

"I've experienced some problems. I couldn't spare much time for my family. Also, we had the chance to repeat the classes but we were actually attending classes physically and I couldn't spare enough time for my child. Mostly my husband took care of my child. At the same time, there were many instances where internet connection was cut off. I wasn't able to connect. So, we weren't able to take the classes. And we had to repeat those classes later on. I had to spare more time for it." (N6)

The opinions of nurses with regards to whether they would prefer to study for a master's degree through distance education again or not is presented in Table 5.

Table 5. The opinions of nurses with regards to whether they would prefer to study for a master's degree through distance education again or not

\begin{tabular}{llll}
\hline $\begin{array}{l}\text { Theme } \\
\text { (Categories) }\end{array}$ & Codes & n & $\%$ \\
\hline
\end{tabular}

$\begin{array}{llll}\text { Whether } & \text { I'd prefer it (N1,N2,N3,N5,N6,N7,N8,N9, } & & \\ \begin{array}{l}\text { distance } \\ \text { education }\end{array} & \text { N10,N11,N12,N14,N16,N17,N18,N19,N20) } & 17 & 85 \\ \begin{array}{l}\text { would be } \\ \text { preferred }\end{array} & \text { I wouldn't prefer it (N13,N15) } & 2 & 10 \\ \text { again } & \text { I'm undecided. (N4) } & 1 & 5\end{array}$

When Table 5 is examined, it can be seen that the most common response with regards to whether the nurses would prefer to study for a master's degree through distance education again, is a yes (85\%). Other responses can be listed as "no" with a rate of $10 \%$ and "undecided" with a rate of $5 \%$. The exact quotes of the nurses' opinions are presented below.

"I'd prefer distance education again. It felt easier to me. I'd never think of getting formal education". (N16) 
"I'd have to opt for it again. Because I have working hours that I have to keep up with and also the responsibilities of my family life. I'd prefer distance education again so that these responsibilities of mine aren't interrupted and so that I could somehow fulfill my educational needs.

The opinions of nurses with regards to whether the master's degree through distance education met their expectations or not is presented in Table 6.

Table 6. The opinions of nurses with regards to whether the master's degree through distance education met their expectations or not

\begin{tabular}{|c|c|c|c|}
\hline Theme (Categories) & Codes & $\mathbf{n}$ & $\%$ \\
\hline How well their & My expectations were met & & \\
\hline expectations of the & $(\mathrm{N} 1, \mathrm{~N} 2, \mathrm{~N} 3, \mathrm{~N} 4, \mathrm{~N} 6, \mathrm{~N} 7, \mathrm{~N} 9, \mathrm{~N} 10, \mathrm{~N} 11, \mathrm{~N} 12$, & 17 & 85 \\
\hline $\begin{array}{l}\text { master's degree } \\
\text { through distance }\end{array}$ & N13,N14,N15,N16,N18,N19,N20) & & \\
\hline education were met & & 3 & 15 \\
\hline
\end{tabular}

When Table 6 is examined, it can be seen that $85 \%$ of the nurses reported that the master's degree through distance education met their expectations, while 15\% reported that their expectations were partially met. The exact quotes of the nurses' opinions are presented below.

"It definitely met my expectations, I received what I needed to receive and learnt what I needed to learn. Our lecturers are also very good. The department is very good as well, so I've really enjoyed it. I'm happy that I did it. And I recommend it to everyone." (N1)

"Of course it met my expectations. In fact, it even exceeded my expectations. My lecturers were very attentive and involved. I was able to ask all kinds of questions and receive answers with ease. I've learned new things at this age. And it made a lot of contributions. It had quite a positive impact on my professional life. It had quite a positive impact on my life at home as well. It affected my relationships with my kids and my husband in a positive way. So it really met my expectations." (N3)

\section{CONCLUSION, DISCUSSION AND SUGGESTIONS}

According to the results of the research, what led nurses to studying for a master's degree through distance education has been the work hours put in during the day because of the professional life and the duties and responsibilities undertaken due to marital status. This research which is carried out with female nurses revealed that the reasons for nurses preferring distance education are mostly family life and professional life. It is considered that this is because the undertaken duties and responsibilities are given first priority by the nurses.

Time and location flexibility which is in the nature of distance education provides great ease and advantages for adult education in occupational groups such as nurses. First of all, it doesn't disrupt the professional life and second of all it doesn't impose problems for family life. In this regard, it is able to contribute to the closing of the educational gap between men and women due to socio-economic reasons.

In "Toward New Horizons for Women in Distance Education: International Perspectives" by Karlene Faith which is one of the first published studies on female learners and distance education, the included reasons for female learners who continue with their education through distance learning were their professional lives and the child care responsibilities they take on due to motherhood. Therefore, they can easily perform their expected duties and responsibilities at home while continuing with their education (Faith, 1988, p:10) (Demiray, 2010).

The reasons why nurses prefer distance education are stated as; not being able to continue with formal education programs due to long working hours/shift work, learning environment which is in accordance with individual learning speed and manner, ease in keeping up with the responsibilities related to family, 
learning times that are scheduled by the learner herself and the opportunity of constant access to materials related to the topic that is being learned (Senyuva, 2013).

It is determined that nurses prefer distance education because; it provides them the opportunity to study from their homes or work places without disrupting their professional lives, it enables them to take responsibility in their own learning experience and provides them with the ability to work according to their own speed, it offers them the flexibility to be able to set their own study schedule and it provides ease in keeping up with the family life (Halter, Kleiner and Hess 2006; Christianson, Tiene and Luft 2002; Daugherty and Funke 1998), (Senyuva, 2013).

When studies made in different countries on distance education is assessed, it can be seen that even though they possess different characteristics, the majority of distance education students consist of adult men and women at the ages of 25-35 who are working and who are either married or have family responsibilities. When this is assessed from a gender point of view, it is concluded that women prefer distance education more than men (Sikora and Caroll, 2002: 4; Holmberg, 1995: 12).

In this study, it is seen that master's degree education through distance learning is generally considered to be effective. Master's degree education through distance learning met the students' expectations of the master's degree education. However, the severity of the IT problems experienced during the education are noteworthy. This rather important means of education has unacceptable problems such as the sound quality being low during class and the connection being affected by natural events.

In a program organized for working students, class hours are scheduled right after the end of the work hours, working students can't find the time to go home and even if they do they coincide with the dinner time of the family members. These are factors that require attention in the planning of these programs. Isman and Dubaj's research results reveal that $85 \%$ of students complain about the lack of mutual interaction in distance education (Isman and Dabaj, 2005).

According to research results, another problem that is experienced during distance education is the lack of sufficient interaction. In another research carried out by Paran, students indicated that they experienced problems in communicating with their lecturers. In addition, lack of sufficient socialization is coined as one of the negative aspects of distance education (Paran, Furneaux and Summer, 2003).

According to the study results, it's possible to put forward suggestions that would increase the availability of master's degree education through distance learning for more people. Distance education is a must for women who are actively employed and who have serious duties and responsibilities at home as well, so that they're able to engage in lifelong learning and to realize their self-potential. People of all ages and professions can organize their own education program according to their individual speed and capacity in a flexible and practical manner while not disrupting their productivity, through distance learning. The IT problems that put a strain on the education must be minimized taking into account the needs of the working female learners, while distance education programs are being planned. In addition, the family and professional lives of female learners must be taken into account as well as the class hours, the upload speeds of class materials and the available hours of the learners, while planning distance education programs tailored to women. Not only descriptive but empirical studies must also be performed on the development and popularization of distance education applications on a higher education level which are tailored to working women.

\section{References}

Akca, O. (2006). SAU Opinions of Distance Education Students regarding Communication Obstacles. Unpublished master's thesis, Sakarya University, Institute of Social Sciences

Alkan, C. (1987). Open education: A comparative review of distance education systems. Ankara: A. U. Faculty of Educational Sciences Publications, No. 137

Atack, L. (2003). Becoming a web-based learner: registered nurses' experiences. Journal of Advanced Nursing, 44 (3), 289-297. 
Beldarrain,Y.(2006).Distanceeducationtrends:Integratingnewtechnologiestofosterstudentinteractionandcollab oration. Distance Education, 27(2), 139-153.

Boz, B. (2008). Specification of educational requirements in online learning and views of learners: An application with regards to healthcare workers. Master's thesis, Anadolu University, the Institute of Social Sciences.

Boz, B., Kurubacak, G. (2008) Design of Distance Education for Students who are Nurses C. U. High School of Nursing Magazine 12(3) 1

Christianson, L., Teine, D. \&Luft, P. (2002). Web-based teaching in undergraduate nursing programs. Nurse Educators, 27,276-282.

Daugherty, M. \&Funke, B.L. (1998). University faculty and student perceptions of web-based instruction. Journal of Distance Education, 13, 1-39.

Demiray, E. (2013). Distance Education and the Importance of Distance Education in Female Education Journal of Education and Training Research 2 (2) 155-168

Demiray, E. (2010) Education of Females and Distance Education. Ankara: Efil Publishing House

Faith, K. (1998). Toward New Horizons for Women in Distance Education: International Perspectives. London: Routledge printed.

Halter, J.M., Kleiner, C. \&Hess, R.F. (2006). The experience of nursing students in an online doctoral program in nursing: A phenomenogical study. International Journal of Nursing Studies, 43, 99-105.

Hipp, H. (1997). Women Studying at A Distance: What Do They Need to Succeed? Open Learning.

Holmberg, B. (1995). Theory and Practice of Distance Education. USA and Canada: Routledge, Second Edition.

İsman, A. and Dabaj, F. (2005). Diffusion of distance education in North Cyprus. Turkish Online Journal of Distance Education (TOJDE) October 2005 ISSN 1302-6488 Volume:6, Number:4, Article:6

Kaya, Z. and Onder, H. H. (2002). "Ergonomics in Training via the Internet "The Turkish Online Journal of Educational Technology (TOJET), Volume 1, Issue 1.

Kramarae, C. (2001). The Third Shift: Women Learning Online, Washington: American Association of University Women Educational Foundation Printed.

May, S. (1997). Women as Distance Training Students: Participation and Technology. Translated by: Nur Ziyaoglu, Open Education Magazine, V:2, No:2, Winter, 1997. (Original Article: Journal of Distance Education, 1994, 9.)

Ozer, B. (2011). The Assessment of Distance Education Programs in terms of the Views of the Students and Lecturers. Unpublished master's thesis, Abant Izzet Baysal University, Institute of Education Sciences.

Paran, A., Furneaux, C. and Sumner, N. (2004). Computer-mediated communication in distance MA programmes: the student's perspective. System 32 (2004) 337-355 was accessed at www.elsevier.com/locate/system on 12.02.2011. 
Sugur, S. and Savran, G.T. (2006). An Examination of the Open Education System in Turkey in terms of Societal Gender. Ankara University, SBF Magazine, 61,3, July-September.

Sikora, A. C. and Carroll, C. D. (2002). A Profile of Participation In Distance Education: 1999-2000 Postsecondary Education Descriptive Analysis Reports, National Center for Education Statistics. Washington: Pedar.

Senyuva, E. (2013) Opinions of Nurses with regards to Distance Education. Education Technology, Theory and Practice, 3(2) 7

Tri-Council for Nursing (2010). Tri-Council for Nursing Issues New Consensus Policy Statement on the Educational Advancement of Registered Nurses was accessed at http://www.aacn.nche.edu/Education-resources/TricouncilEdStatement.pdf on 14.01.2014.

Willmer, M. (2005). Promoting practical clinical management learning: The current situation about information and communications technology capability development in student nurses. Journal of Nursing Management, 13,467-476.

Yildirim, A. \& Simsek, H. (2008). Qualitative research methods in the social sciences Ankara: Seckin Publishing House.

Yuksekdag, B. B. (2014) The Perceptions of Nurses with respect to Distance Nursing Education: A Project Study with a General Purpose, Anadolu University, Faculty of Open Education. 